\title{
RESTORATIVE JUSTICE IN THE SETTLEMENT OF TRAFFIC ACCIDENT CAUSING DEATH TOLL ACCORDING TO THE PERSPECTIVE OF CUSTOMARY JUDICIARY IN SANGGAU DISTRICT, WEST KALIMANTAN
}

\author{
Marina Rona'; Rachmad Safa'at ${ }^{2}$; Abdul Madjid ${ }^{3}$; Mohammad Fadli ${ }^{4}$ \\ 1.2,3,4 Faculty of Law, Brawijaya University, Indonesia \\ Email: marinarona@ymail.com; rachmad.syafaat@ub.ac.id; \\ abd_jidam@yahoo.co.id; mfadlifh@ub.ac.id
}

\begin{tabular}{l}
\hline Article Information \\
\hline Submitted: January 22, 2020 \\
Accepted: May 02, 2020 \\
Keywords: \\
Customary Judiciary; \\
Adat Verdict Pati Nyawa, \\
Restorative Justice. \\
\end{tabular}

\begin{abstract}
This research aims to examine restorative justice in the settlement of traffic accidents caused by the death toll from the customary judiciary perspective in Sanggau Regency, West Kalimantan. The fact of the field shows that a customary judiciary is an option for indigenous people to settle traffic accidents that resulted in the death according to customary decision. The customary judicial process is led by Pomuntuh Adat with deliberation for consensus involving the perpetrators/drivers and heirs of his family and heirs of the victim's family. Adat decision by punishing perpetrators to repay or reinstate victims losses due to criminal acts sanctioned the customary verdict where the perpetrators/drivers and heirs of the family pay customary fines to the heirs of the victim's family and also perform customary rituals as a form of recovery of natural balance. The matter of traffic accident that has been decided through the customary judiciary, it is not processed through the process through the state's prejustice. The research is an empirical legal research, using secondary data through literature studies. Primary Data was obtained through interviews where the results concluded that the settlement of a traffic accident resulting in a death toll in a customary judicial perspective is a real manifestation of restorative justice.
\end{abstract}

\section{Introduction}

The existence of customary criminal law as a law that is alive and develops as long as it is human and its interactions, therefore will not be removed with legislation. Allotment of the customary decision of the pati nyawa to the driver or perpetrators by paying the customary fines of traditional objects such as Tajau Laut (ceramic jars of high 1.3 meters) and a white casing cloth as a substitute body, Lila (small cannon) as a replacement for the spine, a mesh as a substitute for abdominal organs, a wire as a replacement of the veins, gong as a substitute for sound (vocal), Copper Period in lieu of the head, spear and Serampang fish as a substitute for fingers and some other organs of the body.

At the time of payment of the customary fine pati nyawa, the heirs of the family of victims and heirs of family actors/drivers and the representatives of the villagers

Yustisia Volume 9 Number 1 (January-April 2020) Restorative Justice in The Settlement of... 
(Tejomurti, K. 2018: 272-296) and all of the customary momentum must be present to witness the procession. Therefore, the parties/drivers and heirs of the victim's family must prepare food and beverage supplies during the customary process

The issue of a traffic accident on July 11, 2017 precisely on highway Bodok-figure Parindu Sub District, Sanggau District ie a collision between the motor KB 4010 DV driven by Sdr. Hengky bumped into a motor 5612 DD KB causing in the rider IE Alm. The villagers of Layau Hamlet, Desa Palem Jaya, Parindu subdistrict, Sanggau district, died. Then, on July 20, 2017 incident in Balai Berkuak, Ketapang regency where oil tank car PT. Patra Niaga with police number KB 9610 SH driven by Brother Tawi bumped motor that resulted in the rider namely ALMH. Endang villagers Seranggas, village Gunam Parindu Subdistrict, Sanggau Regency passed away. Both cases are victims of Dayak Hibun community, therefore family heirs demanded a settlement based on customary law with the Pati Nyawa Customary Verdict (J.U Lontaan, 1975: 330).

Restorative justice is viewed as a fundamental principle used in criminal cases. Where the perpetrators, victims, and/or other parties can effectively participate in the completion, sometimes the parties in order to assist the settlement of the case act as a facilitator in resolving the problems arising from the crime. Emphasis is placed on the individual or collective interests and reintegration between the perpetrators and victims. By means of deliberation for consensus and based on customs related to the cause. Peace between the two sides with the main joint of the condonation of the victim on the perpetrators of criminal acts is called restorative justice.

Indonesia has the concept of a single Bhineka state Ika, known for its diversity of cultures, religions, tribes, races, and groups. By the de facto, this diversity is reflected in the kemajattening of the Indonesian nation that is framed in the unitary State of the Republic of Indonesia. Indonesia's wide-area extends from Sabang to Maurake with its wide range of natural resources (I Nyoman Nurjaya, 2007: 1). Similarly, the Adat law community of Dayak Hibundi Regency of Sanggau, West Kalimantan. The law known is customary law, which in the event of a breach by a person or group of people will be subject to customary sanctions by traditional momentum through deliberation mechanisms for consensus or better known as customary justice. Customary sanctions are given to restore the disturbed natural balance as a result of the violation. Therefore the community is very familiar with the slogan "Live conceived Adat, dead contained land", this is what is the guideline of living for the Indigenous law community of Dayak Hibun. Based on the background that has been outlined, what is the meaning of restorative justice in the decision of customary pati nyawa in the case of traffic accidents resulting in death toll on the indigenous law community Dayak Hibun?

\section{Research Methods}

This research is a type of empirical legal research to know restorative justice in the settlement of a traffic accident that resulted in death toll in the perspective of the customary judiciary in Sanggau Regency, West Kalimantan. The study also examines the behavior of indigenous Dayak Hibun people, especially in terms of choosing to resolve traffic accidents causing death toll through customary institutions so that indigenous 
peoples of Dayak Hibun have their own meaning of the process of completing the traffic problem known as customs justice. Empirical research is a study that sees the law as a reality, including social reality, cultural reality, etc (Achmad Ali, 2012: 2) Based on deliberations for consensus, indigenous institutions impose sanctions on the perpetrators/drivers, owners and/or public transport companies as well as the heirs of the perpetrator's family by paying a penalty pati nyawa customary verdict.

This research uses the socio-legal-antro approach (Rachmad Safa'at, 2013: 51), which is to assess the behavior of the public law, especially the implementation of adat pati nyawa, case studies on Dayak Hibun customary law community in Sanggau Regency, West Kalimantan. The socio-legal approach to examining the purpose of customary law is the welfare of its community members. In different to the purpose of law established by the State is ensuring legal certainty. To achieve prosperity, not only is a certainty, but also prosperity and justice. Therefore, customary legal research has a great moral responsibility.

The socio-legal approach to examine the purpose of customary law is the welfare of its community members. In different to the purpose of law established by the State is ensuring legal certainty. To achieve prosperity, not only is certainty, but also prosperity and justice. Therefore, customary legal research has a great moral responsibility (Dominikus Rato, 2015: 178).

The law is not separated from the values and attitudes and behaviors that the lawmakers themselves do. Muhamad Munir strengthened this logic by saying: "That the study of law not only concerns the normative aspect of mere but the law can be examined from the empiric aspect of how the law is in reality in people's lives" (Muchamad Munir," 1996: 38).

\section{Research Result and Discussion}

\section{A. Definition of The Restorative Justice}

The pipetting system that focuses on the condemnation and incarceration of a criminal offense encourages the development of the condemnation paradigm called restorative justice, aimed at changing the direction of criminal law by changing its focus on the needs of victims and improving the order of society rather than by simply imprison people. The political law adopted by the State to acknowledge or not acknowledge the customary judiciary is highly relevant to be examined with the theory of justice as a knife of analysis. Law and justice are two sides of the currency thing that cannot be separated, because the essence of the law is justice. Paul Scholten says that the concretization of common norms, the conclusion of certain specific regulations is always more than mere logical work, in any decision (law) of justice to come to speak (Dardji Darmodihardjo and Sidharta, 1999: 154) .

The opinion of Leon Petrazycki on justice can be interpreted as a distinct view of most people who say that justice is abstract. According to Petrazykci, justice is a concrete phenomenon that can be captured through the research of our intuition. As a real phenomenon justice is a psychic phenomenon, knowledge of 
which can be aquired through self-observation and the joint method (Leon Petrazycki, 1995: 241).

The concept of justice is far rooted to Roman times. Justice by the Romans is said to be ius suum clique Tribuerre, the justice should not be viewed as having the same understanding as "the equation". Justice does not mean all peoples gain the same part. Aristotle teaches there are two kinds of justice, the distributive justice and the comutative justice. Distributive justice is justice that gives everyone rations according to his services. Comutative justice is the equation, everyone gains the same allowance regardless of their services (Van Apeldorn, 1958: 20-21) Sudikno Mertokusumo stated in the principle of equality demanded justice in the sense that everyone is equal in the law (equality before the law), everyone is treated equally. Fair is when everyone has the same rights, the same thing should be disconnected (Similia simllibus) (Sudikno Mertokusumo, 1991: 35).

Thomas Aquinas as an adherent of natural law distinguishes justice in two groups, namely General justice and special justice. General justice is a justice that, according to the will of the law, must be demonstrated in the public interest. While special justice is distinguished into distributive justice, comutative Justice and Vindicative justice. Distributive justice is justice that is professionally applied within public law fields in general. The Comutative justice is justice by likening it to accomplishment with contraprestation. Vindicative Justice is justice in terms of punitive or indemnity in criminal acts. A person is treated fairly if he is sentenced to body or fine in accordance with the magnitude of the sentence that has been prescribed for criminal acts (Dardji Darmodihardjo and Sidharta,2013: 154) .

Fairness can also be distinguished into individual justice and social justice. The capitalist countries and the ideology of the construction of justice are more appropriate in the sense of individual justice or in the micro sense, i.e. justice whose execution parameters depend on the personal will. Other than justice in sociological perception, justice is no longer individual, but social is even structural. Social justice is justice whose implementation is no longer dependent on personal wills or individual goodness, but it is already structural. That is, the implementation of social justice relies heavily on the creation of a fair social structure. Social justice can also be deflated as behavior, which is the behavior to give to others what is the right to realize a prosperous society. Prosperity is the primary goal of social justice (Suteki, 2020: 18-19)

Jeremy Bentham, known as Ulitarianism, says that justice is not for individuals, justice is measured by how much it impacts the welfare of society. Individual welfare can be ignored for greater benefit (the benefit of the community). In line with that, a law that gives much happiness to the greatest part of society will be judged as a good law (Lili Rasyidi and Ira Rasjidi, 2001: $64)$. 
John Rawls asks his opinion on the opposite justice with Bentham's opinion. Rawls cannot accept the concept of justice that just thinks of benefits. Rawls argues there needs to be a balance between personal interest and common interest, in the sense that the concept of justice should rely on the rights and obligations (John Rawls, 2006: 72)

Restorative justice is viewed as a fundamental principle used in criminal cases. Where the perpetrators, victims and/or other parties can effectively participate in the completion, sometimes the parties in order to assist the settlement of the case act as a facilitator in resolving the problem arising from the crime. Emphasis is placed on individual or collective interests and reintegration between the perpetrators and victims (....)

Restorative justice refers to ways of deliberation for consensus and based on customs related to the cause. The emphasis is on the concept of a state of diversity that noap that the country is not the only source to realize effective order and justice (M.Ali Zaidan, 2012: 284).

The breakdown of facts and circumstances and tools of evidence is not merely a descriptive description, but there are argumentative considerations prior to the conclusion of the opinion. So it clearly reads the path of logical and reasioning a straightforward mind that is used to support the judgment consideration of the judge (M. Yahya Harahap, 2010: 361). Restorative justice assesses that (Achmad Ali, 2009: 249-250):

a. Crime is a violation of the people and relates to citizens ;

b. Breach of creating obligations;

c. Justice includes victims, transgressors, and citizens in an attempt to put things right;

d. The central focus: The victims need the recovery of losses he suffered (both physically, psychologically, and material) and the perpetrators are responsible for recovering it (usually by way of guilty confession of the perpetrator, apology and regret of the perpetrator and the granting of compensation or restitution)

In the concept of restorative justice, the concept of violation of the law does not lie in the attack on the public interest (Najicha, F. U., \& Hermawan, S. 2019), but the act of offender is considered to result in the loss of victims (victim damages). The concept of restorative justice gives the rationality of the relations of the legal interests between the perpetrators with the crime victims as follows (J.Pajar Widodo, 2013: 130):

1. Criminal acts are not primarily seen as violations of the law, but rather violations by someone against others who are detrimental;

2. Raising awareness of the perpetrator for damage or loss to victims arising from perpetrators, as well as encouraging the growing sense of responsibility for damage or loss of victims;

3. Raising responsibility of the perpetrator no longer repeated his deeds; 
4. Perpetrators are encouraged to conduct their own recovery of any damages or losses arising from his actions;

5. Encourage dialogue between actors and victims who are assisted by other parties such as families or competent officers.

The completion of a restorative justice-oriented criminal case can be attributed to the peace system prevailing in the Indonesian law community for certain criminal matters (Bagir Manan, 2009: 131)

Criminal proceedings that require punishing perpetrators of criminal acts by paying or recovering victims ' losses due to criminal acts are a reflection of restorative justice. Therefore, in the sanction of the traditional pati nyawa decision, the perpetrator pays a customary fine to the heirs of the victim's family and also conducts customary rituals as a form of recovery of natural balance.

\section{B. Pati Nyawa Customary Verdict}

Pati nyawa is defined as the price of blood for each head. Indeed, Ngayau can only be understood in the context of the religious life of Dayak indigenous people (Abu Ahmadi, 1986: 218). The skull of the head was handed over to the family who lost in Mengayau. It must therefore be paid blood price to the heirs of the victim's family. The payment of blood prices was known by Pati nyawa. The customary fine in ancient times was a substitute for organ and the senses of one's death due to being dikayau (P. Yeri, 2016: 317). Since the implementation of a joint agreement between the Dayak tribes known as the term Dayak Agreement 1894 (the result of the amicable meeting of Tumbang Anoi) about the uniformity of Dayak customary law, the Ngayau is officially forbidden (JJ Kusni, 1994: 32). In addition, the spread of the mission of Catholic and Christian religion, education and association of living among ethnic groups and increasing the flow of communication and information among Dayak customary law community is very influential in the cessation of Mengayau habit.

Pati Nyawa is maintained until now as payment for the price of blood and the replacement of the organ of the person who died from human deeds. In particular, this study examines and analyses the customary decision of pati nyawa in the case of casualty traffic accident is the customary law community of Dayak Hibun which is a form of restorative justice. Therefore, despite the perpetration of the outside parties and or not the Adat law community of Dayak, it is still subject to the customary judicial decision (H.Abdurrahman, 2009: vii-ix)

Customary criminal law is a living and developing law as long as there is human and its interactions, therefore it will not be removed with legislation (Hilman Hadikusuma, 1984: 20). Allotment of the customary decision of the pati nyawa to the driver or perpetrators by paying the customary fines of traditional objects such as Tajau Laut (ceramic jars of high 1.3 meters) and a white casing cloth as a substitute body, Lila (small cannon) as a replacement for the spine, a mesh as a substitute for abdominal organs, a wire as a replacement of the veins, gong as a substitute for sound (vocal), Copper Periok in lieu of the head, spear and Serampang fish as a substitute for fingers and some other body organs. 
On payment of fines adat pati nyawa, the heirs of family victims and family members and representatives of villagers and all of the customary pomuntuh must be present to witness and participate in the customary judicial process. As an example of the case of heavy traffic accident on July 11, 2017 precisely on highway Bodok-figure Parindu Sub District, Sanggau district that is the collision between the motor KB 4010 DV driven by Sdr. Hengky bumped into a motor 5612 DD KB that resulted in the driver ie Alm. The villagers of Layau Hamlet, Desa Palem Jaya, Parindu subdistrict, Sanggau district, died. Next on 20 July 2017 incident in Balai Berkuak, Ketapang regency where the oil tank car PT. Patra Niaga with police number KB 9610 SH driven by Brother Tawi bumped motor that resulted in the rider is ALMH. Endang villagers Seranggas, village Gunam Parindu Subdistrict, Sanggau Regency passed away. Both cases of this victim is the customary law community of Dayak Hibun, therefore the heirs of the family demanded a settlement under customary law with the ruling adat pati nyawa.

Payment verdict adat pati nyawa held with a series of sanctions adat sanggah parang, adat dahaso buai giling, adat bepasoah, adat penosak, adat pati nyawa pengganti organ tubuh dan adat mahabo dan besopak In detail can be explained as follows:

1. Adat Sanggah Parang, Executed as soon as possible after a traffic accident in which there are victims who died, this custom aims to relieve the emotions of the victim's family.

2. Adat Dahaso Buai Giling, executed with the intention to appeal to the creator for safety and health and avoid danger to the heirs of family victims or villagers.

3. Adat Bepasoah, executed to make the funeral procession done running safely and smoothly.

4. Adat Penosak, Aims to impose a fine amount of errors that will be dropped to the driver/perpetrator based on the examination of customary criminal cases by listening to the information of witnesses and information actors/ drivers.

5. Adat Pati Nyawa Ganti Badan dan Jiwa, aims to replace body organs and life victims with traditional objects, so that the family or heirs do not feel lost

6. Adat Mahabo dan Besopak is carried out to separate the souls of victims who died with family heirs, thereby they can carry out the activities of daily life without being shaded-in the spirit of the victim.

Dayak Hibun indigenous peoples argue that people and the universe are integral to each other, packed in a cosmological, thinking construction. Therefore, to achieve happiness and balance of nature, then all behaviors must take into account the supernatural powers that do not appear and conform to the ordinances as they have been established. Any violation of customary law or customary criminal action will result in damage not only to the body and human life (victims), but also cause interference or shaking in the magical realm due to natural imbalance. This brings consequences, not enough to settle the 
matter is outwardly but also must include the restoration of natural balance with traditional rituals (I Made Widnyana, 2013: 110)

The second amendment of the 1945 Constitution of the Republic of Indonesia provides recognition and respect for indigenous peoples, as article 18B paragraph (2) which states "the State recognizes and respects the unity of the Indigenous Law community and its traditional rights throughout the life and in accordance with the development of the society and the principles of the unitary Republic of Indonesia, which is governed by law". Furthermore, article 28 i verse (3) states that: "The identity of cultural and traditional rights is respected in accordance with the development of the Times and civilizations". Therefore, the mandate contained in the Constitution must be obeyed by the state organizers (Sudikno Mertokusumo, 2001: 37-38).

\section{Customary judiciary for indigenous peoples}

The unity of customary law community in Indonesian territory, using the terms are very diverse to mention the mechanism of settlement of things (disputes/abuses) are often called customs justice. Terms used such as traditional Council councils, customary meetings or typical expressions of each region (Tim Editor AMAN-Partnership for Governance Reform, 2010: 8)). The community with the mechanism of customary law in the view that every crime or offense, not to be denied as crimes or violations of the state, but rather the social problem of society, which put the process of completion involving the community itself, especially the parties (perpetrators and victims) and heirs/families with the mechanism of deliberation for consensus and the completion of the problem through the mechanism of customs The customary judiciary can play a role in the utilization of local wisdom as a conflict resolution through local and informal prenup mechanisms. Indigenous peoples prefer this mechanism rather than the formal/state judicial mechanisms

In the customary law community, Dayak Hibun uses the term "adat Bokuduong" which is a commonly used term. The customary Bokuduong is a joint meeting to discuss the various issues of life of the Adat law of Dayak Hibun, both concerning customs and customs violations. Matters relating to customs, usually related to traditional equipment or customs that are prepared when they want to do a traditional ritual. For example, when you want to build a new house, the person who is coerted first prepares the traditional equipment such as Letitia as one of the symbols in the traditional ritual. In this case it is not interpreted as a violation of customs, but more to the customs. However, in case of customary violations, the process of completion of the problem is known as "Bahada" or Bucaho. In Bucaho/Bahada ", then the parties present and involved in the process are as follows (Interview with Temonggong A. Lidos on August 18, 2018 at Desa Baharu, the village of Suka Gerundi):

1. Pomuntuh Adat, is a customary institution known as a adat organization consisting of Temonggong, Pateh/Mangku, Hiyo/Jago/Singo, Pasirah; 
2. Parties with litigants including heirs;

3. Let pucaho From both sides of the litigants, people who are good at the customary law appointed by the parties that litigate;

4. The witnesses, usually appointed by the parties;

5. Village device, each of which is representative of the parties;

6. Indigenous peoples, taking part in the process of completing a.

The case of traffic accidents resulting in death toll, then after the process Bucaho/Bahada held, then the magnitude of the sanction or fines known as Tango term ( Interview with Taher as Temonggong Hibun Dahik, on 24 July 2018 at Damai Central Village ) decided by the customary pomuntuh according to its authority. Dayak Hibun Customary Law community in Sanggau district, West Kalimantan chose to use the customary judiciary as an institution to resolve traffic accident causing death.

The customary judiciary that emerges and develops naturally and genuine in togetherness with the inception of indigenous peoples ' unity, that is the nature of the customary judiciary referred to in this paper. Therefore, the customary judiciary remains in existence as long as there is life of the customary law community itself. It is described in the daily practice of the lives of indigenous peoples of Dayak West Kalimantan in general, still resolving disputes and or their causes through customary judiciary.

According to the explanation above, the concept of customs justice can be described as follows::

1. The customary judiciary is a living judicial system in the unity of Indigenous law communities in Indonesia;

2. Customary judiciary based on customary law;

3. The customary judiciary is not part of the state judicial system;

4. Customary judiciary to prosecute customary matters, whether in the form of disputes or violations of customary law;

5. Customary judicial authorities prosecute matters between citizens of indigenous and foreign law Community unity

Dayak Hibun Indigenous peoples, choose to settle their matters through customary judiciary, on the basis of several reasons, among others,:

1. Trustworthy, for the parties who have a common justice is a trusted institution. Because the traditional Pomuntuh are people who have integrity and honesty and work selflessly. Their daily life also lives with the customary law community itself.

2. Deliberation consensus, that in the process of the trial in the customary court then all are open so that the parties can be directly involved.

3. Open, that the process of traditional Bucaho in particular related to the traffic accident that resulted in the death toll was carried out openly and attended by various parties. 
4. Fast, the case of traffic accidents resulting in death toll is carried out rapidly, especially related to the traditional Sanggah Parang after the incident.

5. Sincere, the indigenous pomuntuh who judges during the Bucaho work in an Iklas and full of responsibility.

6. Peace, that the process of Bucaho Adat was carried out peacefully between the parties perpetrators/defendants with the victim.

7. Fair, is done in a fair where the traditional Pomuntuh always consider every statement either from the perpetrator/defendant or the party of the victim.

8. Joint responsibility, decision on the adat penalty/fines is ajoint responsibility, both heirs/family of victims and perpetrators.

9. Sustainability, that the customary judicial process needs to consider the sustainability of the parties

The political reality of the unification Law on the state judiciary has denied the existence of customary law and customary judiciary. So that any dispute resolution or cause defeed the law of the State and the state judiciary. However, customary law and customary judiciary far before the Republic of Indonesia was proclaimed. So that the customary judiciary should have a place in judicial authority in Indonesia that shows legal pluralism, including judicial bodies, so that the recognition of the existence of customary justice as a judicial system outside the state in addition to the existence of the judicial system of the state

\section{Structure And System of The Customary Judicial System}

If one imagines the customary judiciary as imagined the structure and the judicial system of the state that has offices with complete facilities and with the salaried judges, then people will get lost and do not find any customary justice. The customary judiciary is a judicial system that was born, developed and practiced by indigenous Community law communities in Indonesia, based on customary law, where the judiciary is not part of the state judicial system.

Along with the development of the era with the number of population is increasing, where the needs of life and problems that arise in society more and more and must be handled, so they divide the task in the Authority on the implementation of community life and traditional pomuntuh, consisting of::

1. Temonggong is the highest indigenous Pomuntuh which has indigenous territories consisting of several villages and or village;

2. Mangku/Pateh is Pomuntuh Adat that holds the customary area of a few kampongs in the indigenous territory of a Temonggong, so in the life of the community serves as a helper/deputy Temonggong;

3. Domuong is a Pomuntuh Adat that holds the indigenous land of one village only and is usually given the title of Hiyo/Nato/Hango/Jayo/Singo;

4. Kebayan/Pesirah is Pomuntuh Adat in one village as a helper/deputy Domuong;

5. Pongurus/Disabling is Pomuntuh Adat in one village as a helper/deputy Kebayan/Pesirah 
They are people who understand and proficient and have integrity in complaint adat law issues so that when paired with the state judiciary, it is done by the customary judges. The process of solving a case or known as Bucaho using customary law is better known as the term Customs justice

\section{Conclusion}

The completion of the traffic accident resulting in death toll through customary judiciary is manifest by involving the driver/perpetrator, owner and/or public transport company and the heirs of the perpetrator's family and the heirs of the victim's family and local customary law community. The allotment of customary sanctions not only focuses on the perpetrators but examine more in the inheritance of the victim's family, such as the sustainability of life after the victim abandoned. The payment of pati nyawa customary sanctions is not only borne by the driver/perpetrator only. However, customary sanctions are also borne by the owner and/or public transport company and heirs of the perpetrator's family and the heirs of the victim's family. Therefore the customary judicial process to the payment of fines on ruling adat pati nyawa concist ot Body and organ that accompanied by traditional ritual that is recovery of natural balance is a tangible manifestation of restorative justice.

The determination of the fine judgment of the customary pati nyawa is done by the institution that has the justification on the basis of historical values and values of socio-anthropology, where the customary pomuntuh are the people of choice who think of integrity and understand customary laws and are in their communities. Thus, the customary decision of pati nyawa has a value of benefits especially for the heirs of family victims and communities in general. In addition, the decision of adat pati nyawa has the value of fairness and benefit by focusing on the heirs of family victims and the restoration of natural balance.

\section{BIBLIOGRAPHY:}

Abu Ahmadi. (1986). Antropologi Budaya: Mengenal Kebudayaan dan Suku-Suku Bangsa di Indonesia. Surabaya: Pelangi.

Achmad Ali and Wiwie Heryani. (2012). Menjelajahi Kajian Empiris terhadap Hukum. Jakarta: Pranadamedia Group.

Achmad Ali. (2009). Menguak Teori Hukum (Legal Theory) dan Teori Peradilan (Judicialprudence) Termasuk Interpretasi Undang-Undang (Legisprudence). Jakarta: Prenadamedia.

Bangir Manan (2009). Menegakkan Hukum Suatu Pencarian. Jakarta: Asosiasi advokad Indonesia-MMIX.

Dominikus Rato. (2015). Hukum Adat Kontemporer. Surabaya: LaksBang Justitia.

Derrida dalam Roger Cotterrel. (2001). Sociological Perspective on Law, England : Dartmouth Publishing Company and Ashagate Publishing Companny. 
Hedar Laujeng. (2003). Mempertimbangkan Peradilan Adat: Seri Pengembangan Wacana. Jakarta: HuMa.

H.Abdurrahman dalam kumpulan tulisan. (2009). Mengenal Sistem Peradilan Adat 25 Sub Suku Dayak di Kabupaten Sanggau. Pontianak: Lembaga Bela Banua Talino.

Hilman Hadikusuma. (1984). Hukum Pidana Adat. Bandung: Alumni.

I Gusti Ketut Sutha. (1987). Bunga Rampai Beberapa Aspek Hukum Adat. Yogyakarta: Liberty.

I Made Widnyana. 2013. Hukum Pidana Adat Dalam Pembaharuan Hukum Pidana. Jakarta: Fikahati Aneska.

I Nyoman Nurjaya.(2007). Reorientasi Paradigma Pembangunan Hukum Negara dalam Masyarakat Multikultul perspektif Antropologi Hukum, Pidato Pengukuhan Guru Besar Dalam Bidang Ilmu Hukum Pada Fakultas Hukum Universitas Brawijaya Malang,.

JJ Kusni. (1994). Dayak Membangun: Kasus Dayak Kalimantan Tengah, Universitas Michigan: SN.

J.F. Holleman. (1981). van Vollenhoven on Indonesian Adat Law: Selection from het Adatrecht van Nederlandsch-Indie.

J.U Lontaan. (1975). Sejarah-Hukum Adat dan Adat Istiadat Kalimantan Barat, Pontianak: Pemerintah Tingkat I kalbar.

John Rawls. (2006). Teori Keadilan. Yogyakarta : Pustaka Pelajar.

J.Pajar Widodo. (2013). Menjadi Hakim Progresif, Bandar Lampung: Indepth Publishing.

Leon Petrazycki. (1955). Law and Morality, Cambridge Massachusetts: Harvard University Press.

Lili Rasyidi and Ira Rasjidi. (2001). Dasar-dasar Filsafat Dan Teori Hukum, Bandung: Citra Aditya Bakti.

P. Yery OFM Cap. (2016). Adat Istiadat Orang Dayak Landak dan Tayan, Yogyakarta: Pohon Cahaya.

Mattew B. Miles and A. Mitchael Huberman. (1992). Analisis data kualitatif: Buku Sumber tentang Metode-Metode Baru. Jakarta: UI Press.

Muchamad Munir. (1996). Penggunaan Pengadilan Negeri Sebagai Lembaga Untuk Menyelesaikan Sengketa Dalam Masyarakat. Surabaya: Unair..

M. Yahya Harahap. (2010). Pembahasan Permasalahan dan Penerapan KUHAP: Pemeriksaan Sidang pengadilan, Banding, Kasasi, dan Peninjauan Kembali (edisi kedua). Jakarta: Sinar Grafika.

Najicha, F. U., \& Hermawan, S. (2019, October). Law in the Globalization and Its Influence on Economic Development and Environmental Preservation based on Pancasila and the Indonesian Constitution of 1945. In 3rd International Conference on Globalization of Law and Local Wisdom (ICGLOW 2019). Atlantis Press.

Noer Sidharta Effendi. (2016). Mahkamah Konstitusi dan Perlindungan Hak Sosial Masyarakat Hukum Adat, Makalah pada Constitutional Law Festival di Universitas Brawijaya: Malang. 
Rachmad Safa'at. (2013). Rekonstruksi Politik Hukum Pangan, Dari Ketahanan Pangan Ke kedaulatan Pangan. Malang: UB Press.

Sudikno Mertokusumo. (1991). Mengenal Hukum Suatu pengantar, Yogyakarta: Liberty.

Suteki. (2010). Rekonstruksi Politik Hukum Hak As Air Pro Rakyat. Malang : Surya Pena Gemilang.

The Liang Gie. (1972). Teori-Teori Keadilan : Sumbangan Bahan Untuk Pemahaman Pancaslla. Yogyakarta : Super.

Tejomurti, K. (2018). Memberdayakan Koperasi Sampah Berbasis Otonomi Desa Dalam Mewujudkan Desa Ramah Lingkungan dan Berkelanjutan. Law Review, 17(3), 272296.

Valentinus. (1997). Kehormatan Menurut Dayak Mualang dalam Perspektif Kehormatan Katolik, Tesis, STFT Widya Sasana: Malang.

Van Apeldorn. (1958). Pengantar Ilmu Hukum, Jakarta : Noorhoff-kol NV.

Noor Sidharta Effendi. (2016). Mahkamah Konstitusi Dan Perlindungan Hak Sosial Masyarakat Hukum Adat, Makalah pada Constitutional Law Festival di Universitas Brawijaya, 7 Oktober 2016. 